\title{
SECONDARY ELECTRON EMISSION INDUCED BY $\alpha$-PARTICLES FROM Mg-MgO LAYERS
}

\author{
V.P. Zhurenko ${ }^{1}$, S.I. Kononenko ${ }^{\text {, I.S. Mahotka }}{ }^{1}$, O.V. Kalantaryan ${ }^{1}$, I.M. Mysiura ${ }^{1}$, \\ S.S. Avotin', N.Ya. Rokhmanov ${ }^{2}$ \\ ${ }^{1}$ V.N. Karazin Kharkiv National University, Kharkiv, Ukraine; \\ ${ }^{2}$ Kharkiv National Agrarian University, «Dokuchaieske-2», Kharkiv region, Ukraine
}

The paper presents the results of experimental study of forward and backward electron emission induced by $\alpha$ particles from the deposited film of magnesium. It was shown that during the deposition of magnesium in residual gas atmosphere the deposited film contained a large amount of $\mathrm{MgO}$ component, which makes it possible to consider the resulting structure as $\mathrm{Mg}-\mathrm{MgO}$. The presence of magnesium oxide on the surface of the target and the collector leads to the fact that the previously obtained dependence of the ratio of forward and backward electron yields on specific energy loss of the ion for various metals is not applicable in the case of deposited magnesium. The differences are explained by the specificity of the emission from magnesium in the presence of a significant amount of $\mathrm{MgO}$. The results obtained can be used to detect $\mathrm{MgO}$ on the surface of a magnesium substrate. It was shown the differences in the experimental data for the bulk magnesium collector and the collector with deposited magnesium layer.

PACS: 79.20.Rf78

\section{INTRODUCTION}

Secondary ion-induced electron emission is a fundamental effect of ion interaction with matter. The differences between so-called forward (the direction of the projectile movement) and backward (the opposite direction) electron emissions have been intensively studied for the last 25 years (see e. g. $[1-4]$ ). The parameter characterizing the differences between these types of emissions is the Mekbach factor $R$, defining the relation between forward and backward electron yields [5]. Physical differences are associated with production of fast emission electrons through direct collisions of bombarding ions with atoms of a substance: convoy and $\delta$-electrons, those momenta are oriented mainly in the direction of projectiles (see e. g. $[6,7]$ ). Most of the researches devoted to $R$ study were carried out using ultra-thin films. The cycle of forward-backward investigations was carried out by Rothard's group with fast accelerated multiply charged ions and a thin carbon film [8 - 9]. It should be noted that in these experiments the projectile energy at the entrance and exit of the foil was somewhat different (part of the energy was lost by the projectile in the foil), and therefore specific energy losses of ion were differed too. But as we know, electron yield is proportional to the mentioned above losses [10], so there was additional disadvantage of thin foil forward-backward emission experimental study. Therefore, we performed the cycle of $R$ factor measurements at the same ion energy earlier [11 - 13]. It was shown that $R$ factor measured by us for a number of metals and founded from Rothard's experiments [8] for carbon foils depended on the specific energy loss of fast ions in a substance.

Great interest are attracted to secondary electron emission application of $\mathrm{MgO}$ in efficient emitter development (see e. g. [14 - 17]). $\mathrm{MgO}$ is used as additional component to the base material of emitters. Magnesium is chemically active element, so its oxides are often formed during a number of technological operations, such as sputtering, spraying, implantation.

In this work, we studied the effect of magnesium oxide layers, obtained naturally by thermal deposition on thin magnesium foil, on forward and backward electron yields of secondary electron emission induced by $\alpha$ particles of the same energy.

\section{EXPERIMENTAL SETUP}

Emission experiments were performed on the experimental setup, which described in detail in [11]. A source of $\alpha$-particles, a thin foil target and a bulk collector were placed in the vacuum chamber (Fig. 1). The projectiles were emitted by a radioisotope source with isotope $\mathrm{Pu}^{239}$ (initial flow intensity $4.64 \times 10^{6}$ particles per second). $\alpha$-particles with energy of $5.15 \mathrm{MeV}$ were isotropically radiated into the solid angle $2 \pi$.

The target was an aluminum thin foil of $5.6 \mu \mathrm{m}$ thickness with $\mathrm{Mg}$ deposited layer on one side of the surface. The foil was selected in such a way that its thickness was less than the mean free path of the $\alpha$ particles emitted by this radioisotope in the target material. The radioisotope source and the metal holder of the target were in the electrical contact.

The flux of $\alpha$-particles, passing through the target, caused secondary electron emission from its outer surface (forward emission).

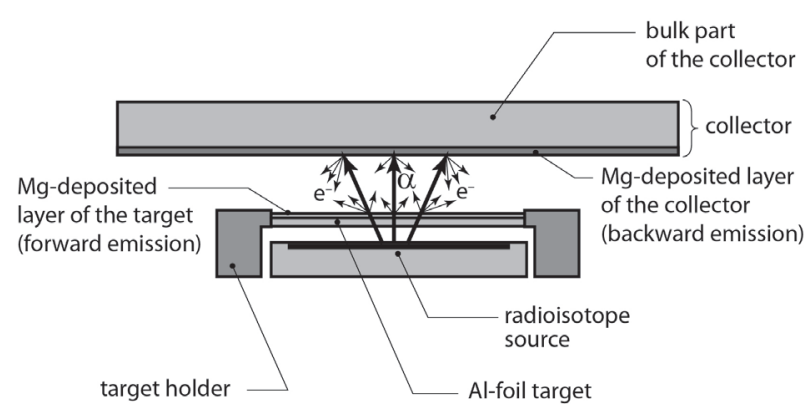

Fig. 1. Scheme of forward-backward electron emission experiments

Then $\alpha$-particles hit the collector and induced electron emission from its surface (backward emission). To provide collection of all emitted electrons both in the case of forward emission from the target and backward emission from the collector, we applied an electric field in the space between target and collector. We applied a potential of amplitude from -300 to $+300 \mathrm{~V}$ to the target 
using a constant-current source of the Keithley-6487 type. We measured the current of $\alpha$-particles and emission electrons in the collector electrical circuit. We used a Keithley- 6487 picoammeter with a sensitivity of $10^{-14} \mathrm{~A}$ for precise current measurements.

The current-voltage characteristics measured in this way allowed to calculate electron yield $\gamma$ from the saturation current, i.e., from the maximum current corresponding to the total collection of emission electrons. Taking into account that we performed current measurement in the experiment, it is possible to calculate $\gamma$ by the expression:

$$
\gamma=2\left(\mathrm{I}_{\mathrm{e}}-\mathrm{I}_{\alpha}\right) / \mathrm{I}_{\alpha}
$$

where $I_{e}$ is the corresponding saturation emission current, $I_{\alpha}$ is the current of $\alpha$-particles that passed through the target and caused the emission; the coefficient 2 characterizes the fact that the charge of the $\alpha$-particle is twice the electron charge.

All emission experiments were carried out in a vacuum chamber at a residual gas pressure approximately $2 \times 10^{-4} \mathrm{~Pa}$.

We performed 2 series of experiments with different target-collector combination: 1) target № 1 is aluminum foil substrate $(5.6 \mu \mathrm{m})$ with deposited $\mathrm{Mg}$-layer with thickness of $0.4 \mu \mathrm{m}$ and bulk Mg-collector № 1; 2) the target № 2 is aluminum foil substrate $(5.6 \mu \mathrm{m})$ with deposited Mg-layer with thickness of $1.8 \mu \mathrm{m}$ and bulk duraluminum collector № 2 with the same deposited Mg-layer $(1.8 \mu \mathrm{m}) . \mathrm{Mg}$ layers on the surfaces of thin foil targets and collector were produced by thermal vacuum deposition of pure $\mathrm{Mg}$ (99.99\%) in vacuum universal station «VUP-5M». The residual gas pressure was approximately $1.7 \times 10^{-3} \mathrm{~Pa}$. Thin $\mathrm{Mg}$ layers were deposited on the outer surface of aluminum foil and face surface of the bulk duraluminum collector (the side of $\alpha$ particle incidence).

\section{RESULTS AND DISCUSSION}

To simulate the passage of $\alpha$-particles through our target, we used the SRIM-TRIM software (Fig. 2) [18]. As can be clearly seen from Fig. 2, straggling of $\alpha$ particles is insignificant in the case of normal incidence. In the absence of the target, the particles emitted by the $\alpha$-source emitted isotropically into the solid angle $2 \pi$. The solid angle into which the $\alpha$-particles moved passing through the target is determined by the thickness of the foil. Indeed, at large exit angles with respect to the normal to the surface, the projectile path in a target foil becomes comparable to the range.

As a result, if a certain angle is exceeded, the $\alpha$ particles cannot leave the target. Thus, initially the monochromatic flow of $\alpha$-particles, passing through the target, would be distributed by energy from 0 to $\mathrm{E}_{\max }$. The maximum energy would correspond to the particles with incidence angle of $0^{\circ}$. In our case, $E_{\max }$ was approximately 4.15 and $3.97 \mathrm{MeV}$ for target № 1 and 2, respectively.

The collector current as a function of voltage applied between the target and collector is shown on Fig. 3 .

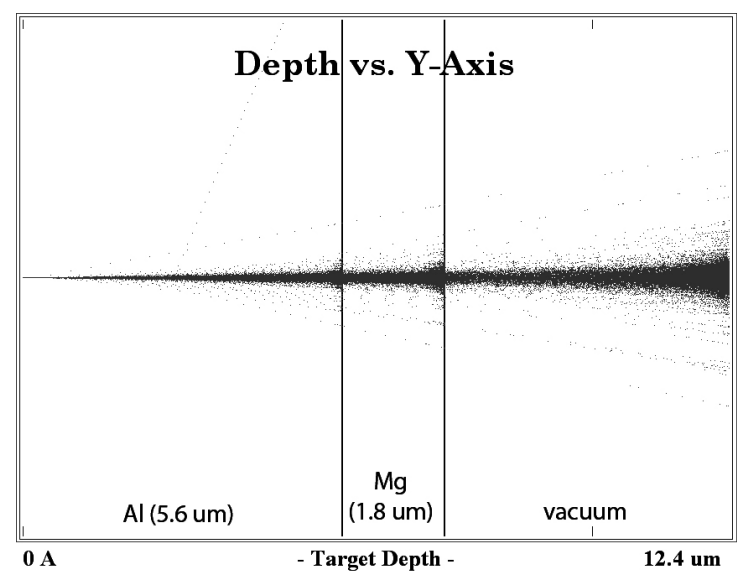

Fig. 2. Ion trajectories in Al-Mg target № 2 for incidence angle of $0^{\circ}$

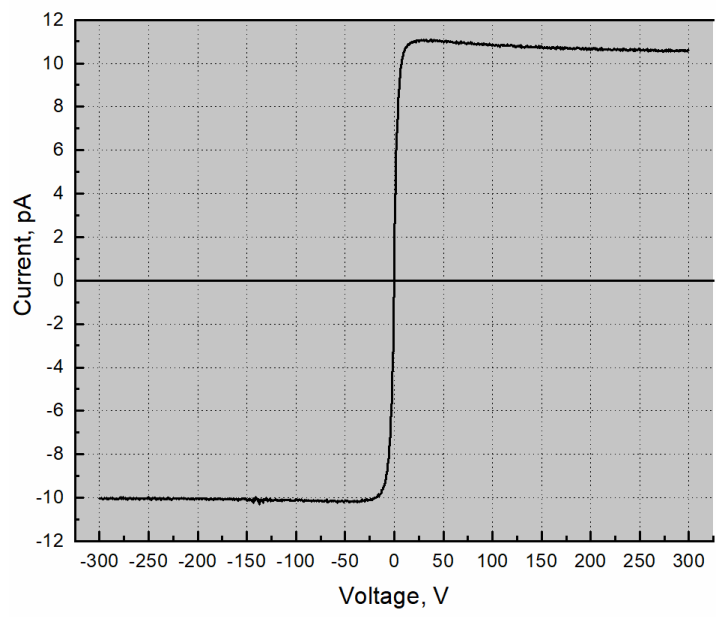

Fig. 3. The experimental current-voltage characteristics for Mg target and Mg massive collector (case 2)

On the basis of measured current-voltage characteristics we calculated the electron yields of forward $\left(\gamma_{F}\right)$ and backward $\left(\gamma_{B}\right)$ emissions for different cases of target-collector pairs (Table).

\begin{tabular}{|c|c|c|}
\hline Target-collector combination & Case 1 & Case 2 \\
\hline$\gamma_{\boldsymbol{B}}$ & 15.8 & 28.37 \\
\hline$\gamma_{\boldsymbol{F}}$ & 28.3 & 30.65 \\
\hline $\boldsymbol{R}$ & 1.79 & 1.08 \\
\hline
\end{tabular}

As can be seen from the table, when $\mathrm{Mg}$ bulk sample was used as a collector, the $R$ ratio between the forward and backward electron yields was approximately 1.79 , which was close to the values obtained earlier by us [11 - 13] and other authors for different substances [8]. Earlier we also found $R$ ratio dependence on the specific energy loss of an ion [13]. According to this dependence, the predicted $R$ value for magnesium should be approximately $1.50 \ldots 1.55$, which is less than the value measured in this experiment (1.79).

The most significant differences were observed for the second case of $\mathrm{Mg}$ layer deposited on the collector. At the same time, the backward electronic yields $\gamma_{B}$ differed by about 2 times for the bulk Mg collector (№ 1) and for $\mathrm{Mg}$ layer deposited on the duraluminum collector (№ 1). While in the case of forward emission the electron yields $\gamma_{F}$ for the targets № 1 and 2 (Mg layers of different thickness), were slightly differed. This slight difference can be explained by the fact that $\alpha$ - 
particles that have passed through the target and cause forward emission, have different maximum energy (due to the difference in thickness of $\mathrm{Mg}$ deposited layers) and, accordingly, different specific energy losses at the exit from the target. As we mentioned above the electron yield is proportional to specific energy loss of fast ion [10]. Since for the deposited layer of greater thickness (case 2), we have larger specific energy loss of $\alpha$ particles at the exit from the target, then larger value of $\gamma_{F}$ for target № 2 is well understood.

The table also shows that the $R$ ratio for the second case is too low 1.08 and is differed from the predicted value. This slight difference in forward-backward emissions induced by ions of the same energy cannot be explained if we deal with metallic Mg layers. Apparently, in our case, the samples were not in a form of $\mathrm{Mg}$ metal film, but the deposited layer were heterogeneous structure of $\mathrm{Mg}-\mathrm{MgO}$, and, most likely, $\mathrm{MgO}$ predominated on the surface. Magnesium oxide compound was formed as a result of the interaction of evaporated magnesium and oxygen from the residual atmosphere of the chamber.

It is known that deposited thin $\mathrm{MgO}$ films, even if it doesn't have an island structure, have a great roughness. As was shown in the work of Yoon [19], regardless of the substrate, the $\mathrm{MgO}$ film had a high roughness. In our case the large surface roughness of deposited layers leads to the fact that $\alpha$-particles, falling on the local area of the surface at different angles, have greater path in the emission layer (the depth of emission layer for electrons is approximately 30 angstroms). Since it is well known that $\gamma$ has inverse cosine law upon incident angle for light ions [20], the proportion of true secondary electrons with respect to fast $\delta$ - and convoy electrons increases significantly. In the case of normal incidence of ion on a surface the fraction of true secondary electrons (with energy less than $50 \mathrm{eV}$ ) is approximately $90 \%$ [11]. Large roughness of the surface leads to significant increase of the fraction of slow electrons in the emitted continuum and, as a consequence, $R$ ratio is decreased.

$\mathrm{MgO}$ is well known as an efficient emitter of secondary electrons. The presence of a dielectric layer on the surface of deposited magnesium leads to the fact that during emission processes the surface is charged, thereby lowering the potential barrier on the surface of magnesium, which leads to a significant increase in electron yield due to emission of slow electrons.

\section{CONCLUSIONS}

The forward and backward electron emission induced by isotropic flux of $\alpha$-particles from $\mathrm{Mg}$ deposited layers was studied. It was shown that using the technique of thermal deposition during the oxidation of magnesium in the atmosphere of residual gas the deposited film contains a large amount of $\mathrm{MgO}$ component, which allow considering it as $\mathrm{Mg}-\mathrm{MgO}$ structure. The presence of $\mathrm{MgO}$ on the surfaces of the target and the collector leads to the fact that the previously obtained dependence of the ratio of forward and backward electron yields on specific energy loss of the ion for various metals is not applicable in the case of $\mathrm{Mg}$ deposited layers. The differences can be explained by the specificity of the emission from magnesium layer in the presence of a significant amount of $\mathrm{MgO}$. The results ob- tained can be used to detect $\mathrm{MgO}$ on the surface of a magnesium substrate.

\section{ACKNOWLEDGMENT}

We would like thank to prof. V. I. Karas' for continuous interest to our work.

\section{REFERENCES}

1. T. Kaneko, Y. Mitsunobu. Forward/backward secondary electron emission from foils by swift ion impact // Nucl. Instr. and Meth. B. 1994, v. 90, p. 560-563.

2. H. Rothard et al. Strong projectile-dependent forward-backward asymmetry of electron ejection by swift heavy ions in solids // Phys. Rev. A. 1998, v. 57 , p. $3660-3664$.

3. H. Ogawa, S. Amano, K. Ishii, T. Kaneko. Forward-backward correlated secondary electron emission depending on the emergence angle of $1 \mathrm{MeV} / \mathrm{u}$ light ions // Nucl. Instrum. Methods Phys. Res. B. 2015, v. 354, p. 96-99.

http://dx.doi.org/10.1016/ j.nimb.2014.09.025.

4. H. Rothard et al. Swift heavy ion induced electron emission from solids // Journal of Physics: Conference Series. 2015, v. 629, p. 012007. doi:10.1088/ 1742-6596/629/1/012007.

5. W. Meckbach, G. Braunstein, N. Arista. Secondary-electron emission in the backward and forward directions from thin carbon foils traversed by $25 \ldots 250 \mathrm{keV}$ proton beams // J. Phys. B. 1975, v. 8, № 14, p. L344-L349.

6. D.H. Jakubassa-Amundsen, H. Rothard. Fast electrons from collisions of highly stripped ions with solid-state targets // Phys. Rev. A. 1999, v. 60, p. 385-391.

7. Y. Yamazaki, N. Oda. Production mechanisms of convoy electrons in ion-foil interactions // Nucl. Instr. and Meth. B. 1985, v. 10/11, p. 161-165.

8. H. Rothard et al. Secondary-electron yields from thin foils: A possible probe for the electronic stopping power of heavy ions // Phys. Rev. A. 1990, v. 41, p. 2521-2536.

9. A. Clouvas et al. Role of projectile electrons in secondary electron emission from solid surfaces under fast-ion bombardment // Phys. Rev. B. 1997, v. 55, p. 12086-12098.

10. E.J. Sternglass. Theory of secondary electron emission by high-speed ions // Phys. Rev. 1957, v. 108, № 1, p. 1-12.

11. V.P. Zhurenko, S.I. Kononenko, V.I. Karas', and V.I. Muratov. Dissipation of the Energy of a Fast Charged Particle in a Solid-State Plasma // Plasma Physics Reports. 2003, v. 29, № 2, p. 130-136.

12. S.I. Kononenko, V.P. Zhurenko, O.V. Kalantaryan, A.A. Semerenskiy. Forward and backward electron emission in binary cell of radioisotope current source // Problems of Atomic Science and Technology. Series "Plasma Electronics and New Methods of Acceleration”. 2015, № 4, p. 331-334.

13. V. Zhurenko et al. $\alpha$-particle induced forwardbackward electron emission from titanium nitride // Problems of Atomic Science and Technology. Series "Plasma Electronics and New Methods of Acceleration”. 2018, № 4, p. 293-296. 
14. A. Kumar, S. Thota, D. Deva, J. Kumar. Ioninduced secondary electron emission, optical and hydration resistant behavior of $\mathrm{MgO}, \mathrm{Mg}-\mathrm{Mo}-\mathrm{O}$ and Mg-Ce-O thin films // Thin Solid Films. 2014, v. 556, p. 260-269.

15. J. Li et al. Au Doping Effect on the Secondary Electron Emission Performance of MgO Films // Materials. 2018, v. 11, p. 2104 doi: 10.3390/ma11112104.

16. F. Zhou et al. Surface Characterization and Secondary Electron Emission Properties of Alumina Containing $\mathrm{MgO}$ Film on Ag-Mg-Al Alloy // Metals. 2018, v. 8, p. 570. doi: 10.3390/met8080570.

17. W. Yi et al. Secondary electron emission from magnesium oxide on multiwalled carbon nanotubes // Appl. Phys. Lett. 2002, v. 81, № 6, p. 1098-1100.
18. J.F. Ziegler, J.P. Biersack, U. Littmark, SRIM The stopping and range of ions in matter // Nucl. Instrum. Methods Phys. Res. B. 2010, v. 268, p. 1818-1823. http://dx. doi.org/10.1016/j.nimb. 2010.02.091

19. Jong-Gul Yoon, Hun Kyoo Oh, and Sung Jong Lee. Growth characteristics and surface roughening of vapor-deposited $\mathrm{MgO}$ thin films // Phys. Rev. B. 1999, v. 60 (4), p. 2839-2843.

20. D. Hasselkamp et al. Particle Induced Electron Emission II // Springer Tracts in Modern Physics. 2006, v. 123.

Article received 25.06.2019

\section{ВТОРИЧНАЯ ЭЛЕКТРОННАЯ ЭМИССИЯ, ИНДУЦИРОВАННАЯ $\alpha$-ЧАСТИЦАМИ ИЗ СЛОЕВ Mg-MgО \\ В.П. Журенко, С.И. Кононенко, И.С. Махотка, О.В. Калантарьян, И.Н. Мисюра, С.С. Авотин, Н.Я. Рохманов}

Приведены результаты экспериментов по исследованию эмиссии электронов, индуцированной $\alpha$ частицами на прострел и на отражение из напыленной пленки магния. Было показано, что при напылении магния в атмосфере остаточного газа пленка содержит большое количество компонента $\mathrm{MgO}$, что позволяет рассматривать полученную структуру как $\mathrm{Mg}-\mathrm{MgO}$. Наличие окиси магния на поверхности мишени и коллектора приводит к тому, что полученная ранее зависимость отношений электронных выходов на прострел и на отражение от удельных потерь энергии иона для различных металлов не применима в случае напыленного магния. Полученные различия объясняются спецификой эмиссии из магния при наличии значительного количества $\mathrm{MgO}$. Полученные результаты могут быть применены для детектирования $\mathrm{MgO}$ на поверхности магниевого субстрата. Были показаны и объяснены различия в экспериментальных данных для массивного магниевого коллектора и коллектора с напыленным слоем магния.

\section{ВТОРИННА ЕЛЕКТРОННА ЕМІСІЯ, ІНДУКОВАНА $\alpha$-ЧАСТИНКАМИ 3 ШАРІВ Мg-МgО В.П. Журенко, С.І. Кононенко, І.С. Махотка, О.В. Калантар'ян, І.М. Мисюра, С.С. Авотін, М.Я. Рохманов}

Наведено результати експериментів з дослідження емісії електронів, що індукована $\alpha$-частинками на простріл і на відбиття з напилених плівок магнію. Було показано, що в разі напилення магнію в атмосфері залишкового газу утворена плівка містить велику кількість компонента $\mathrm{MgO}$, що дозволяє розглядати отриману структуру як $\mathrm{Mg}-\mathrm{MgO}$. Наявність окису магнію на поверхні мішені та колектора призводить до того, що отримана раніше залежність відносин електронних виходів на простріл і на відбиття від питомих втрат енергії іона для різних металів не може бути застосована в разі напиленого магнію. Отримані відмінності пояснюються специфікою емісії з магнію за наявності значної кількості $\mathrm{MgO}$. Отримані результати можуть бути застосовані для детектування $\mathrm{MgO}$ на поверхні магнієвого субстрату. Було показано і пояснено відмінності в експериментальних даних для масивного магнієвого колектора і колектора 3 напиленим шаром магнію. 